\title{
Research
}

\section{Fire, Livelihoods, and Environmental Change in the Middle Mahakam Peatlands, East Kalimantan}

\author{
$\underline{\text { Unna Chokkalingam }}^{1}, \underline{\text { Iwan Kurniawan }}^{1}$, and $\underline{\text { Yayat Ruchiat }}^{1}$
}

\begin{abstract}
Large-scale, recurrent fires in Indonesia in recent decades have caused widespread deforestation and transformation of peatlands, and have contributed to substantial smoke haze and greenhouse-gas pollution. In some areas, local community use of fire for livelihood needs could be a major factor behind the widespread fires. We assessed fire patterns and their causes from the 1980s to the present in the Middle Mahakam peatlands of East Kalimantan. This was achieved through satellite image and GIS analysis, biological and social field surveys, and rapid rural appraisals in the villages. People living in or using the swamps employ fire annually along the waterways and adjacent open floodplains and forests, in conjunction with fishing, agriculture, and other livelihood activities. Local communities perceive that uncontrolled burning does not affect the fish, which is their economic mainstay. Dry and windy conditions, failure of regular livelihoods, new markets for turtles and tree bark, and easing of government quotas for these resources led to more widespread fires in the El Niño periods of 1982-1983 and 1997-1998. Repeated burning ultimately transforms larger and larger areas of peat forest into open floodplains and shallow lakes. Local communities promote the transformation, believing it enhances fishing conditions. Even if the interior forests were kept fire free for a lengthy period, they would likely not fully recover, but these areas were rendered highly fire prone during the last El Niño event in 1997-1998. Another long drought in the near future, coupled with widespread community burning, could cause more severe, long-lasting damage to the peat forests and contribute substantially to regional smoke haze and greenhouse-gas pollution. This paper discusses the scope for resolving the trade-offs between the communities' perceived benefits of fire use, and national and global environmental concerns arising from peatland burning.
\end{abstract}

Key Words: East Kalimantan; El Niño; Fire; Fishing; Livelihoods; Mahakam; Peatland; Turtles

\section{INTRODUCTION}

Indonesia contains vast peatland areas of around 17-27 million ha, or 53\% of the world's tropical peatlands (Soetjipto et al. 1996). Lowland peatlands across Indonesia and Southeast Asia are naturally vegetated with a mosaic of specialized closed forests linked to local hydrological and nutritional conditions (Rieley and Ahmad-Shah 1996, Shepherd et al. 1997). They are unique reservoirs of biodiversity although reputedly less diverse in plant species than lowland rainforests on drier terrain (Shepherd et al. 1997). They are also critical components of the global carbon cycle, estimated to store as much as $2875 \mathrm{t} \mathrm{C} / \mathrm{ha}$ (Maltby and Immirzi 1993), with overall sequestration rates of $0.01-0.03$
Gt C/year (Neuzil 1997). Peatlands are important water catchment and control systems, regulating flows, mitigating floods, and preventing saline water intrusion (Rieley et al. 1997). Indonesia's peatlands are also major breeding grounds and sources of fish for domestic consumption and export (Giesen and Sukotjo 1991, MacKinnon et al. 1996).

In recent decades, fires in Indonesia have increased in scale and frequency, and peatlands in particular have been severely affected (Anderson and Bowen 2000, Siegert et al. 2001, Page et al. 2002). Environmental impacts of peatland fires are enormous. In the 1997-1998 El Niño event, peat and swamp forest fires accounted for 2.1 million ha or $18 \%$ of the total area burned in Indonesia 
(Tacconi 2003), but contributed 60\% of the region's acrid haze (Asian Development Bank/National Development Planning Agency (ADB/BAPPENAS) 1999). An estimated 0.81-2.57 Gt of carbon was released to the atmosphere from burning peat and vegetation, an amount equivalent to $13-40 \%$ of the mean annual global carbon emissions from fossil fuels (Page et al. 2002). Fires and associated disturbances resulted in widespread deforestation and transformation of peatlands, with as yet unclear impacts on local livelihoods. Once altered, peatlands are very susceptible to repeated burning. Recurrent fire has emerged as a major threat to peatland conservation, sustainable use, and restoration where severely altered, as evidenced across Sumatra and Central and West Kalimantan (Chokkalingam et al. 2005, Suyanto et al. 2004, personal communications and media reports).

Large-scale transmigration and plantation development by the government and companies are the major driving forces behind peatland fires in Central Kalimantan and parts of Sumatra (Anderson and Bowen 2000, Page et al. 2002, Suyanto et al. 2004), but there is increasing evidence that local community use of fire for agriculture, fishing, and other activities could also be an important factor in much of Sumatra and Kalimantan, including the major fires during long drought periods (Jepson et al. 1998, Dennis et al. 2000, Chokkalingam et al. 2005, Chokkalingam and Suyanto 2004).

If community burning is a significant factor and communities benefit from fire use, this has major management and policy implications. A blanket ban on fire use is hardly likely to be effective, particularly in the extensive remote peatland areas and without community backing. Feasible and effective fire control and peatland conservation policies will have to consider local livelihood needs and the characteristics of the swamp environment itself. Authorities will also have to seriously consider the possible consequences of bringing in large numbers of people or improving access to as yet undisturbed peatlands as part of development policies. Large expanses of remote peatlands in Indonesia are now being drained and converted into timber and estate crop plantations. Their population is increasing with an influx of company employees and spontaneous migrants seeking resources and incomes.

The Middle Mahakam peatland ecosystem in East Kalimantan represents one of a few important inland freshwater swamp habitats in Kalimantan. This ecosystem, with its natural closed forests, holds a diversity of plant and animal species (Chokkalingam et al. unpublished manuscript, Gönner 2000;

Wetlands International). It contains up to 500 million tonnes of peat carbon (Chokkalingam et al. unpublished manuscript), is an important source of fish for local communities, and is the main supplier of dried freshwater fish imported into Java in the 1980s (Zehrfeld et al. 1985 cited in MacKinnon et al. 1996).

These peatlands have experienced large-scale fires in two recent El Niño periods, 1982-1983 and 19971998 (Lennertz and Panzer 1983, Siegert et al. 2001). Prior to this, major prolonged droughts were recorded in the Middle Mahakam peatlands in 1877-1878 and 1914, with accompanying widespread fires in 1914 (Bock 1881, Brookfield et al. 1995). Hope et al. (submitted manuscript) provide a detailed analysis of the long-term fire history of these peatlands and conclude that major fires are probably restricted to the last few centuries. The 1997-1998 fires appear to have originated from extensive burning by villagers in the course of turtle harvesting in the peatlands (Jepson et al. 1998). Historical literature (Endert 1927) suggests that burning vegetation for fishing purposes may be a traditional practice in the area. In this case study, we investigate the patterns of, and underlying forces driving, recent fires in the Middle Mahakam peatlands, in order to understand the nature of the fire problem. We used a combination of satellite image and GIS analysis, and field biological and social surveys. We depict the importance of burning to meet livelihood needs of communities living in or using the inhospitable swamps, and show how uncontrolled local fire use, when expanded and intensified, could become a major factor driving widespread fires, and thus transforming peatlands.

We examine future scenarios based on the present condition of the ecosystem and assuming that current activities and fire use will continue. Finally, we explore management and policy options for balancing the trade-offs between immediate local livelihood needs and national to global environmental concerns (biodiversity and carbon losses, smoke and greenhouse-gas pollution, and hydrological change) arising from the widespread alteration of these and other peatlands. 


\section{STUDY AREA}

The Middle Mahakam peatlands are in the Kutai Lowlands in East Kalimantan, about $60 \mathrm{~km}$ inland from Samarinda (Fig. 1). The 500 000-ha basin is traversed by the relatively narrow (1-4 km wide) silty clay levee systems of the Mahakam River and major tributaries (Sungai Belayan, Kedang Kepala and Kedang Rantau) (Fig. 2). Behind the levees are a series of shallow peat lakes and seasonally inundated plains, followed by large forested peatlands rising gently to the surrounding lowlands. The peatlands are largely ombrogenous, acidic, and nutrient poor, with the peripheral areas subject to riverine inundation (field surveys). The largest shallow peat lakes include Danau Jempang, Melintang, Semayang, and Siran. The study site was limited to the major peatlands north of Danau Jempang, and the Mahakam River, which is the area within a single LANDSAT image scene (Fig. 2). Our field surveys show that peat depth averages 8 $\mathrm{m}$ and is greater than $15 \mathrm{~m}$ in some areas.

Temperatures are relatively constant through the year, ranging from $25-30^{\circ} \mathrm{C}$. Rainfall in the area averages $1900-2000 \mathrm{~mm}$ per year, with heavy rains from December to April (calculated from Weidemann 2002). In the wet season, the lakes and rivers expand and flood the neighboring peatlands to depths of up to $3 \mathrm{~m}$. Rivers fall by 5-6 m, and lake levels drop to $1 \mathrm{~m}$ or less in the dry season, roughly from July to September (field surveys). During El Niño years, the December-April rains fail and the dry season can extend for up to 8-12 months (Brookfield et al. 1995, social surveys). At such times, the peatlands can dry out, greatly increasing the fire hazard. Monthly rainfall in Samarinda was $\leq 100 \mathrm{~mm}$ from May-October 1997 and then again from January-April 1998, roughly $750 \mathrm{~mm}$ in total from May 1997 to April 1998 (van Nieuwstadt 2002). Monthly rainfall in Kota Bangun was $<100 \mathrm{~mm}$ from July-November 1982 and then again from January-April 1983, roughly $875 \mathrm{~mm}$ in total from July 1982 to June 1983 (Lennertz and Panzer 1983).

The study site includes the 62 500-ha Muara Kaman nature reserve between the Kedang Kepala and Kedang Rantau rivers (Fig. 2). To the northeast of the study site, in the drylands, is the Kutai National Park. Most of the study site was allocated to logging concessions in the 1970s, but scarcely touched because of the low value of the timber and access difficulties. There has been no large-scale commercial logging, land conversion, or infrastructural development within the peatlands, although there are timber plantations and some transmigration development in the surrounding drylands. There has been some recent exploration for oil and oil palm establishment.

Roughly 60 villages are situated along the major rivers within the study area, and many are more than 100 years old. People living in and using the swamps are predominantly from the Kutai and Banjar ethnic groups (social surveys). They have traditional claims on the alluvial strips, including the nature reserve, which they use for cultivating rice, fruit, and rattan. They use the nearby peatlands and lakes on an open-access basis for harvesting fish, reptiles, sedges, timber, and fuel wood. They have also harvested wood since 2001 for a medium-density fiber mill in the area. Fishing, however, is the primary source of livelihood. Local people have dug canals in the peatland between Sungai Belayan and Danau Siran for fishing. These canals appear to be strictly policed and maintained, with charges levied for the fish and reptiles harvested there (Fig. 2). The practice of making canals to open new fishing areas in the peatlands appears to be very old.

People enter the peatlands primarily through rivers, canals, and the lakes. Water levels drop in the dry season, making navigation in shallower areas difficult. The marketability of swamp products, such as fish, reptile skins, and woven mats, has recently improved with the building of new roads from major towns to villages such as Sabintulung on the periphery of the swamps.

\section{METHODS}

\section{Social Surveys in the Villages}

Rapid rural appraisals were used in a sample of villages spread across the study site to gather information about local land and fire use over time, recent fire patterns and their underlying causes, major developments, ecological conditions, and livelihood sources. Appraisals were performed over the wet and dry seasons of years 2000 to 2001. The research team lived in the villages and established good rapport with the communities. The general patterns of responses matched across villages, and also with the direct observations made and key respondent interviews at the field locations (see 
Fig. 1. Location of the Middle Mahakam Peatland study site along the Mahakam river in East Kalimantan. Dark patches are wetland areas of Borneo (Source: World Conservation Monitoring Center).

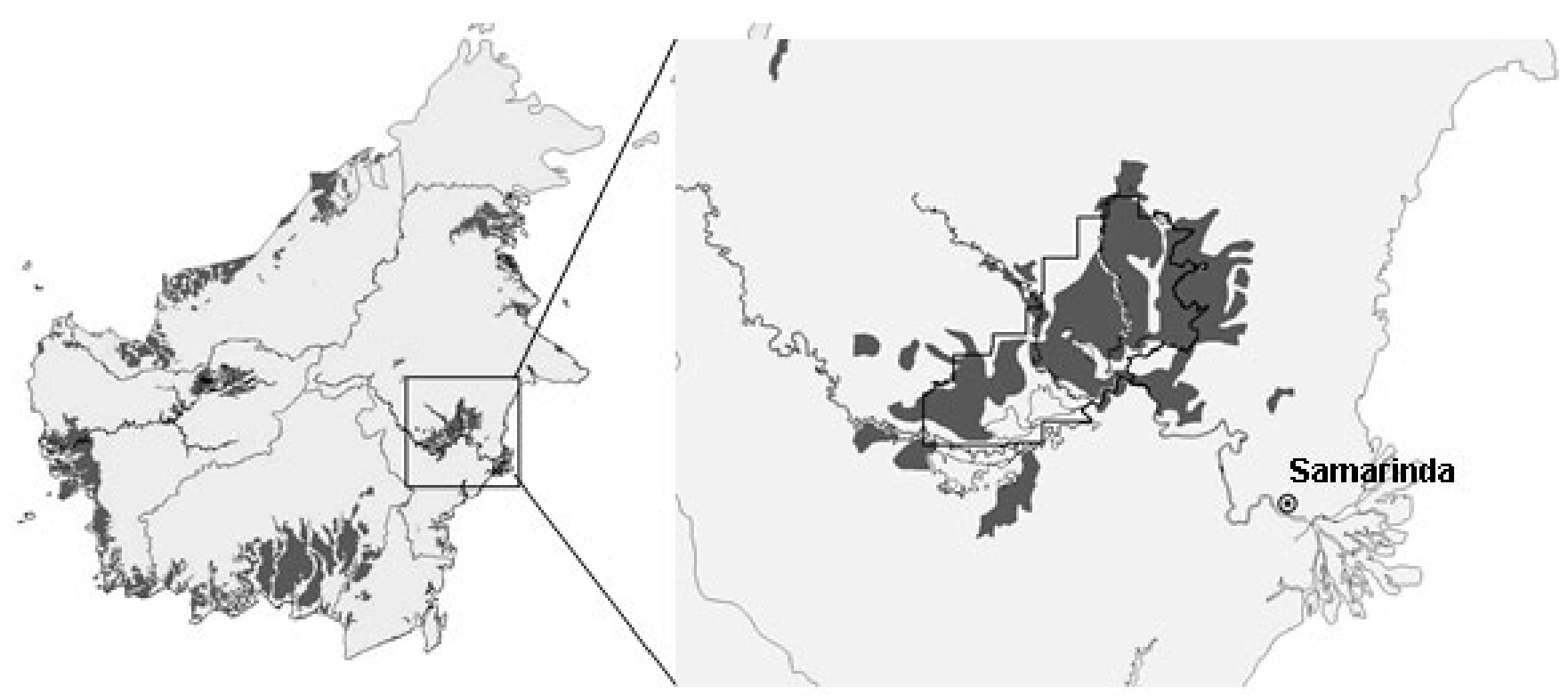

field survey section below).

\section{Vegetation Classifications}

An unsupervised classification of land cover was first performed on a geometrically corrected, spectrally enhanced LANDSAT image (Path/Row $117 / 060$ ) for year 2000. Ecological surveys (see below) were carried out in August-September 2001, and provided field data on vegetation, soils, and hydrology. The focus was on peatlands; drylands and alluvial strips, as confirmed by the field surveys, were masked out for these analyses. The data were used to check and narrow down the land-cover classes into 10 distinct classes discernible on the ground. Similar unsupervised classifications of LANDSAT imagery from earlier years $(1987,1992$, and 1997) were also conducted, based on and crosschecked for consistency with the ground-verified classification from 2000.

\section{Field Ecological and Social Surveys and Analyses}

Field surveys were carried out during the dry season in August-September 2001 along 18 transects (totalling $24 \mathrm{~km}$ ) spread across the peat landscape to cover different spectral signatures in the imagery, and related site types and disturbance histories. Sample points were located $200 \mathrm{~m}$ apart along the transects, with additional site descriptions at every $100 \mathrm{~m}$. Around each sample point (and beyond for land-use and fire history), ecological, land-use, and fire-history parameters were assessed. Sample points were overlaid and assigned to different vegetation types based on the classification. Plots within a single vegetation type on each transect were grouped together as a patch, and ecological data averaged for each of these patches across the landscape.

Ecological parameters included vegetation composition and structure, regeneration, soil characteristics, hydrology, fuel load, and peat loss with burning (Chokkalingam et al. unpublished manuscript). The potential for forests to recover was assessed based on the regeneration data. Fire susceptibility was 
Fig. 2. Key features of the Middle Mahakam study site.

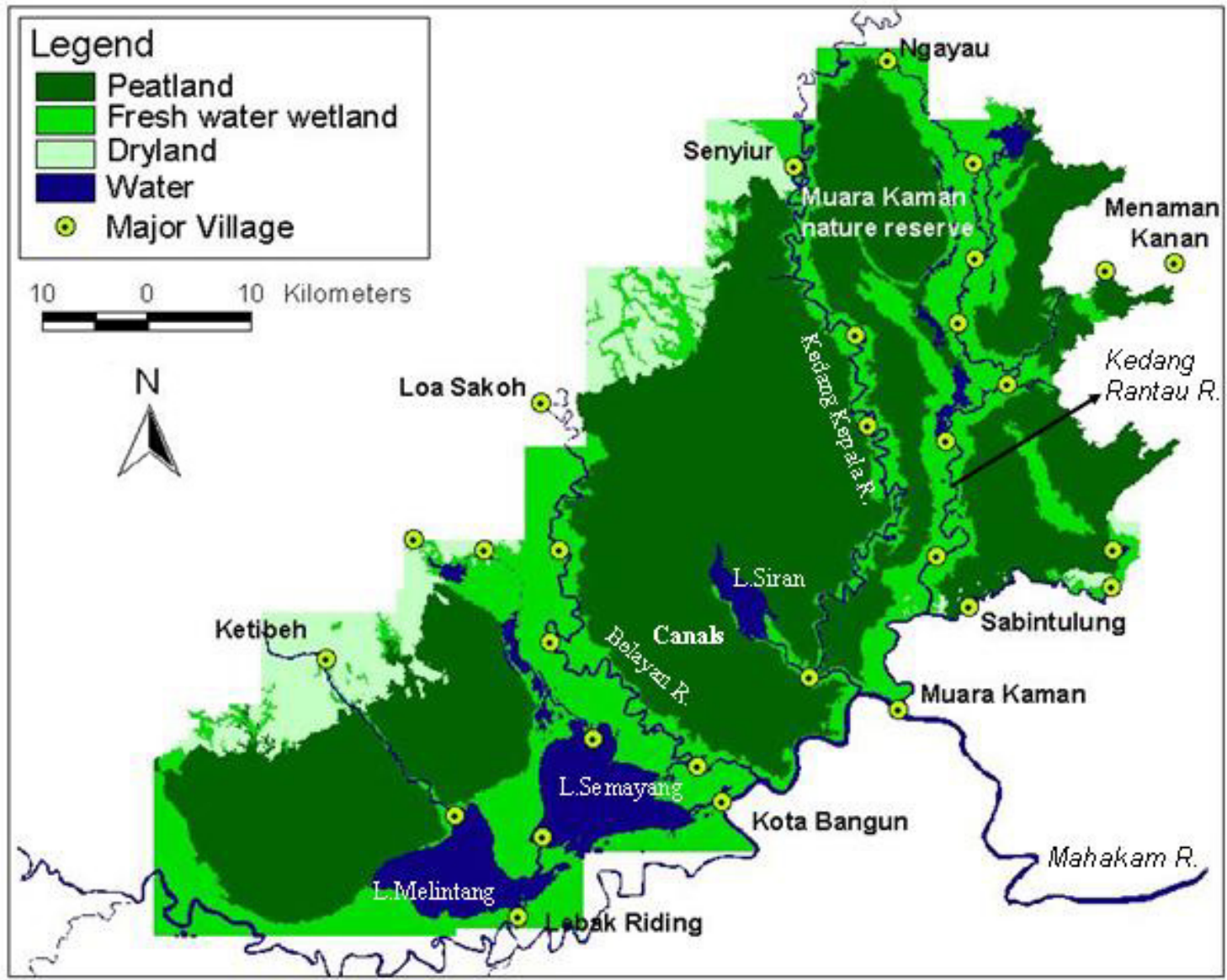

assessed based on vegetation composition and structure, fuel load, and hydrology (Chokkalingam et al. unpublished manuscript).

Community respondents familiar with the longterm history and local ecological conditions were chosen to assist with the field surveys in each area. They were interviewed at each sample point for information on patterns and causes of burning at the location, as well as land-use activities. In addition, direct observations were made of local land- and fire-use practices at the different locations in both the wet and dry seasons.

\section{Fire Patterns}

Fire maps (indicating areas burned) were produced for the periods before 1987, 1987-1992, 19921997, and 1997-2000. Fire occurrence during a given period was detected by identifying areas recently burned or in a more degraded vegetation type between adjacent vegetation classifications in the time series (as in Jakubauskas et al. 1990). Information from the field surveys was used to determine whether vegetation changes could be attributed to fire. At each sample point, information on fire frequency, intensity, timing, and purpose was obtained by assessing stand composition and 
structure; charcoal markings on trees, stumps, and logs; charcoal, ash, and burnt soil in the soil profile; and field interviews.

\section{RESULTS AND DISCUSSION}

\section{Recent Fire Patterns and Causes}

There were major fires in the extreme drought years of 1982-1983 and 1997-1998, and minor fires in all other years (this study, Lennertz and Panzer 1983, Siegert et al. 2001). Fires in the Middle Mahakam peatlands are human induced for livelihood purposes. People do not generally control the fires because it is too hard to do so in the swamps and it is not considered necessary. There is a high risk of uncontrolled fires spreading in drought years, particularly into more open disturbed forests.

\section{2-1983 El Niño fires}

Satellite image analysis for burn scars, supported by field evidence and social interviews, suggests that at least 45\% (101 $854 \mathrm{ha}$ ) of the peatlands in the study site were in degraded vegetation types in 1987. This indicates previous burning, including the fires in the 1982-1983 El Niño event (Fig. 3a, Table 1). Interviews with local respondents, burn scar analyses, and the literature (Lennertz and Panzer 1983) suggest that the fires in the 1982-1983 El Niño season spread from annual burn areas close to the waterways inland into the adjacent dry peat forests (Fig. 3a). The fires also possibly arose from increased human activity within the adjacent forests themselves during the 8- to 13-month long drought period, which limited fishing and agricultural activities. The lakes were dry, and river levels dropped (Lennertz and Panzer 1983, Schindele et al. 1989, Brookfield et al. 1995). Respondents stated that the peat soils were very dry and also burned along with the vegetation during this period. Schindele et al. (1989) mention that strong winds helped fires ignite and spread at this time.

Forest cover regrew rapidly following the 19821983 fires. Scrubby vegetation and open-canopy forests developed into more medium-canopy and then closed-canopy forests by 1997 (Table 2).

\section{Annual fires}

Only 24 and $17 \%$ of the peatlands were burned in the subsequent non-El Niño periods of 1987-1992 and 1992-1997, respectively (Fig. 3b and 3c). The fires occurred primarily in accessible areas along the rivers, lakes, and canals around the edges of the main bodies of peat, as well as adjacent open sedgegrass or barren peat floodplains passable by boat in the wet season. Local communities and migrants use uncontrolled fire here frequently (almost on an annual basis) to:

- clear shrubby and herbaceous growth along the rivers, lakes, and canals (see location of canals in Fig. 2) to avoid vegetative encroachment into the waterways and improve access into the peatlands for collecting fish and other resources (Fig. 4a)

- create, expand, and maintain open sedgegrass or barren peat floodplains inland from existing water bodies by burning or thinning out the vegetative growth. Flooding increases when the peat soil is burned or the structure collapses with vegetation removal. Boats can then enter these reputedly good open-water fish habitats in the wet season (Fig. 4b).

- create pools of water in the more proximate degraded peat forests and shrublands further inland. These pools provide refuge for fish even in the dry season. New pools are created when peat collapses or is lost with heavy burning under dense herb or shrub patches, and under tree roots and downed logs (Fig. 4c). Fire also helps expand and keep these pools clear of encroaching vegetative regrowth. As well, fires serve to keep the swamps themselves more open and accessible, making it easier to locate the pools and access the fish in them, by burning off the surrounding vegetation.

- provide flushes of nutrients that stimulate algal growth and maintain high levels of fish populations, as reported for the Sungai Negara wetlands in South Kalimantan (MacKinnon et al. 1996). 
Fig. 3. Area affected by fire (conservative estimate) before 1987; and between 1987-1992, 1992-1997, and 1997-2000 in the Middle Mahakam study site.
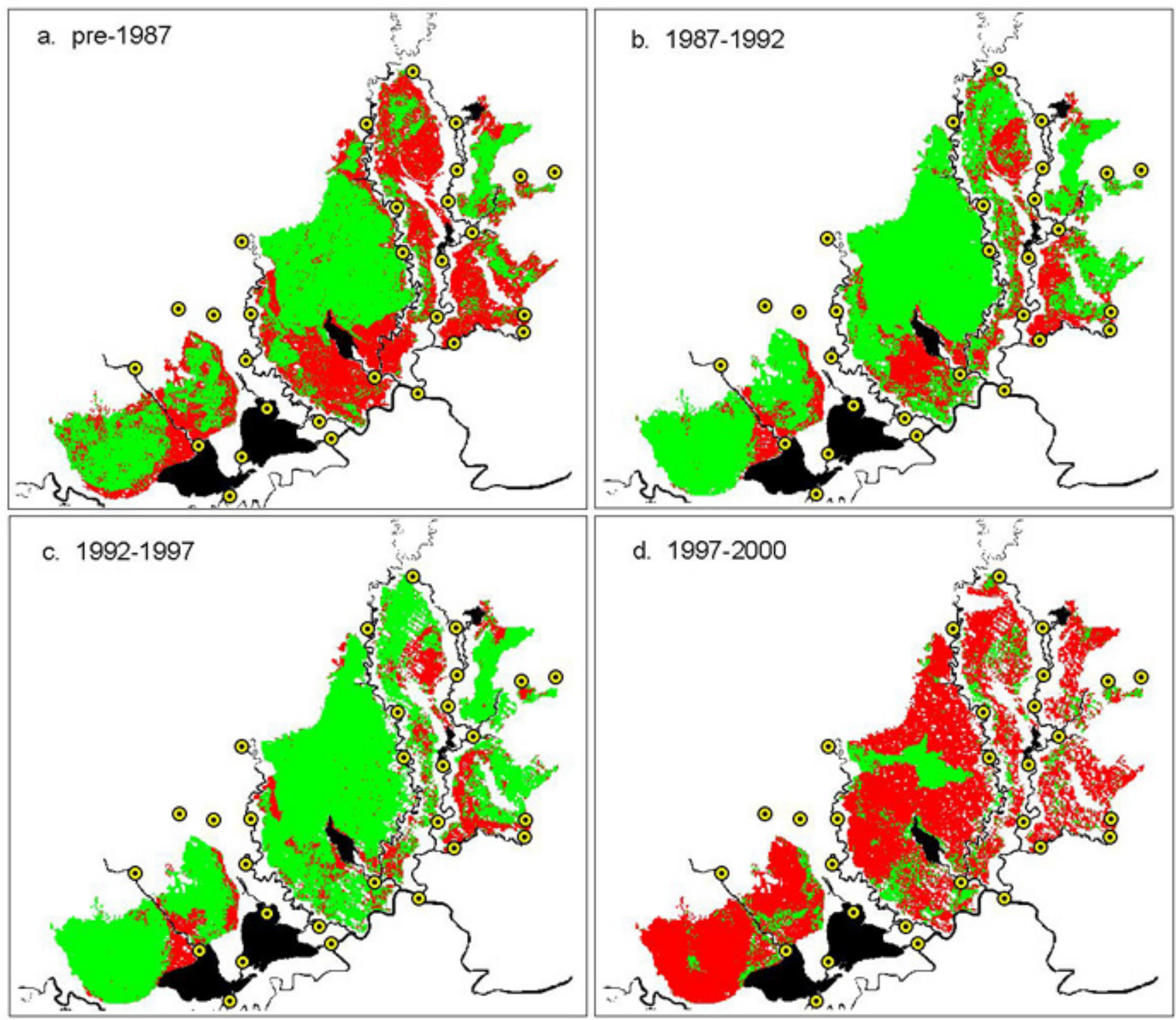

\begin{tabular}{|c|c|c|}
\hline \multicolumn{3}{|l|}{ Legend } \\
\hline No Fire & & Cloud and Shadow \\
\hline Fire & $\odot$ & Major Villages \\
\hline Water & & \\
\hline
\end{tabular}
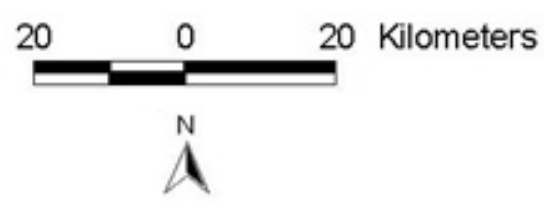
Table 1. Estimated percentage of area burned in each of four time periods in the Middle Mahakam study site

\begin{tabular}{lclcc}
\hline \hline Time Period & $\begin{array}{l}\text { Percentage of Percentage of area in Column 2 burned in } \\
\text { area burned } \\
\text { previous time periods }\end{array}$ & $\begin{array}{l}\text { Percentage of area } \\
\text { under cloud }\end{array}$ & $\begin{array}{l}\text { Total (ha) } \\
\text { (Includes effect of 1982-1983 El Niño fires) }\end{array}$ \\
\hline Pre-1987 & 45 & $\begin{array}{l}81 \% \text { of this area also burned pre-1987 } \\
1987-1992\end{array}$ & 24 & $\begin{array}{l}91 \% \text { of this area also burned pre-1987 and/or 1987- } \\
1992\end{array}$ \\
$1992-1997$ & 17 & $46 \%$ burned in earlier years, 54\% newly burned & 6 & 226342 \\
$1997-2000$ & 72 & & 13 & 226342 \\
\hline
\end{tabular}

Historical literature (Endert 1927) suggests burning for fishing purposes may be a traditional practice. Peat burning usually occurs only in long drought periods when the surface peat is dry.

\section{7-1998 El Niño fires}

In the period 1997-2000 (mostly in the 1997-1998 El Niño season), around $72-85 \%$ of the peatlands were burned; $54 \%$ of this area was mature forest that had not burned within the last two decades at least (Table 1, Fig. 3d). These fires burned all but a small flat area in the center of the largest peat mass and a few other scattered fragments. Interviews with local respondents and burn scar analyses indicate that these extensive fires were caused by extremely dry conditions and burning by local communities and migrants in the course of turtle hunting and collecting tree bark (possibly Alseodaphne sp.).

Fishing, the main livelihood source, was constrained by the drop in river levels, which made navigation and transport of fish difficult. New highvalue markets emerged for turtle meat, and for tree bark as an ingredient in commercial mosquito coils (this study, Jepson et al. 1998). The local government permitted quota-free collection of turtles in response to the drought crisis. Thousands of people switched to these alternative activities and entered interior peat forests that had scarcely been visited before. They also discovered new pools for fishing, which may be visited again, particularly during climate crises. Tree bark collection was carried out mostly to the northwest of the area, whereas turtle hunting was widespread throughout the study site, although more intensive in the big peat patches west of the Semayang and Melintang lakes. Fire was used to improve access into the forest, for camping, and to concentrate the turtles in damp areas and catch them easily by burning off the surrounding vegetation (this study, Jepson et al. 1998). Although these activities got local people through a difficult drought year as intended, they resulted in widespread fires that damaged the entire peat ecosystem and contributed to the smoke and haze problem.

Local respondents say land clearing for forestry plantations and local burning in heath forests in the surrounding uplands played a minimal role, if any, in the peatland fires of 1997-1998. Monthly hotspot data from 1997 to 1998 (GTZ Integrated Forest Fire Management Project, Samarinda) also suggest that the fires originated from activities within the swamps. Following the 1997-1998 fires, closedcanopy forests decreased drastically from 63 to $4 \%$ of the landscape, and medium-canopy forests declined from 8 to $5 \%$ (Table 2). At least $83 \%$ of the landscape is now in secondary successional vegetation types compared with $33 \%$ in 1987 . This includes open-canopy forests, which increased from 1 to $20 \%$; scrubby vegetation, which increased from 11 to $33 \%$; and sedge-grasslands, which increased from 11 to $30 \%$ of the landscape.

\section{Expanding zone of recurrent burning}

Repeated burning has occurred on an annual basis in many newly opened-up areas since 1997-1998, transforming partially burned peat forests into open floodplains, with removal of tree cover and collapse and loss of peat. Local respondents suggest it is common for areas opened up in long drought periods to be subsequently burned repeatedly and transformed in this manner for fishing purposes. The 
Table 2. Percent cover of different vegetation types on the Middle Mahakam Peatlands from 1987 to 2000

\begin{tabular}{lccrr}
\hline \hline Peat vegetation type & $\mathbf{1 9 8 7}$ & $\mathbf{1 9 9 2}$ & $\mathbf{1 9 9 7}$ & $\mathbf{2 0 0 0}$ \\
\hline Closed canopy forest & $\mathbf{5 2 . 9}$ & $\mathbf{5 4 . 0}$ & $\mathbf{6 2 . 7}$ & $\mathbf{4 . 4}$ \\
Medium canopy forest & & 10.7 & 8.0 & 5.1 \\
Open canopy forest & 9.8 & 5.9 & 1.3 & 20.0 \\
Degraded \& secondary forest & $\mathbf{9 . 8}$ & $\mathbf{1 6 . 6}$ & $\mathbf{9 . 3}$ & $\mathbf{2 5 . 2}$ \\
Scrub & 8.8 & 10.6 & 7.5 & 5.6 \\
Light regrowth & 3.8 & 3.4 & 3.9 & 5.7 \\
Shrubland & 3.0 & 4.1 & & 16.3 \\
Standing water & 3.8 & & & 5.4 \\
Scrubby vegetation & $\mathbf{1 9 . 3}$ & $\mathbf{1 8 . 1}$ & $\mathbf{1 1 . 4}$ & $\mathbf{3 3 . 0}$ \\
Flooded herbaceous & 10.4 & 1.8 & 1.1 & 6.5 \\
Wet herbaceous & & 7.5 & 6.5 & 12.1 \\
Dense herbaceous & 4.9 & 1.9 & 3.1 & 11.6 \\
Sedge-grasslands & $\mathbf{1 5 . 4}$ & $\mathbf{1 1 . 3}$ & $\mathbf{1 0 . 7}$ & $\mathbf{3 0 . 1}$ \\
Water & $\mathbf{0 . 7}$ & $\mathbf{0 . 1}$ & $\mathbf{3 . 1}$ & $\mathbf{0 . 1}$ \\
Cloud & $\mathbf{2 . 0}$ & & $\mathbf{2 . 8}$ & $\mathbf{7 . 1}$ \\
Total (ha) & $\mathbf{2 2 6}$ & $\mathbf{2 2 6} \mathbf{3 4 2}$ & $\mathbf{2 2 6} \mathbf{3 4 2}$ & $\mathbf{2 2 6} \mathbf{3 4 2}$ \\
\hline
\end{tabular}

existing floodplains and shallow peat lakes were formed in this way. Once burned and altered, there tends to be a feedback loop of intensive use, further fires, and transformation that expands the fire frontier inland into more remote swamps. Similar feedback loops have been reported by Chokkalingam et al. (2005) for southern Sumatra and by Cochrane et al. (1999) for forests in the Amazon.

\section{Driving Forces Behind Widespread Community Fire Use}

- $\quad$ Fire is an invaluable tool for communities using resources in swamps

Unlike in dryland environments, sustainable livelihood options in the swamps are limited and often involve land and fire uses that deplete or degrade the forests. Swamps are difficult and expensive to access, to convert into alternative land uses, such as permanent agriculture or plantations, or to exploit for timber. Fire is used by communities to access available swamp resources, for camping, and to enhance fish habitat. Currently, there are no effective alternatives to fire use or incentives to avoid it.

- $\quad$ Fish are more valuable than peat forest flora to swamp inhabitants

Peatland trees and other flora appear to have played a minimal economic role historically. The surrounding upland forests provided most of the valuable commercial timber and 
Fig. 4. a) Annually burned vegetation along a river, b) annually burned sedge floodplain navigable by boat, c) pool of water containing fish in a burnt forest.
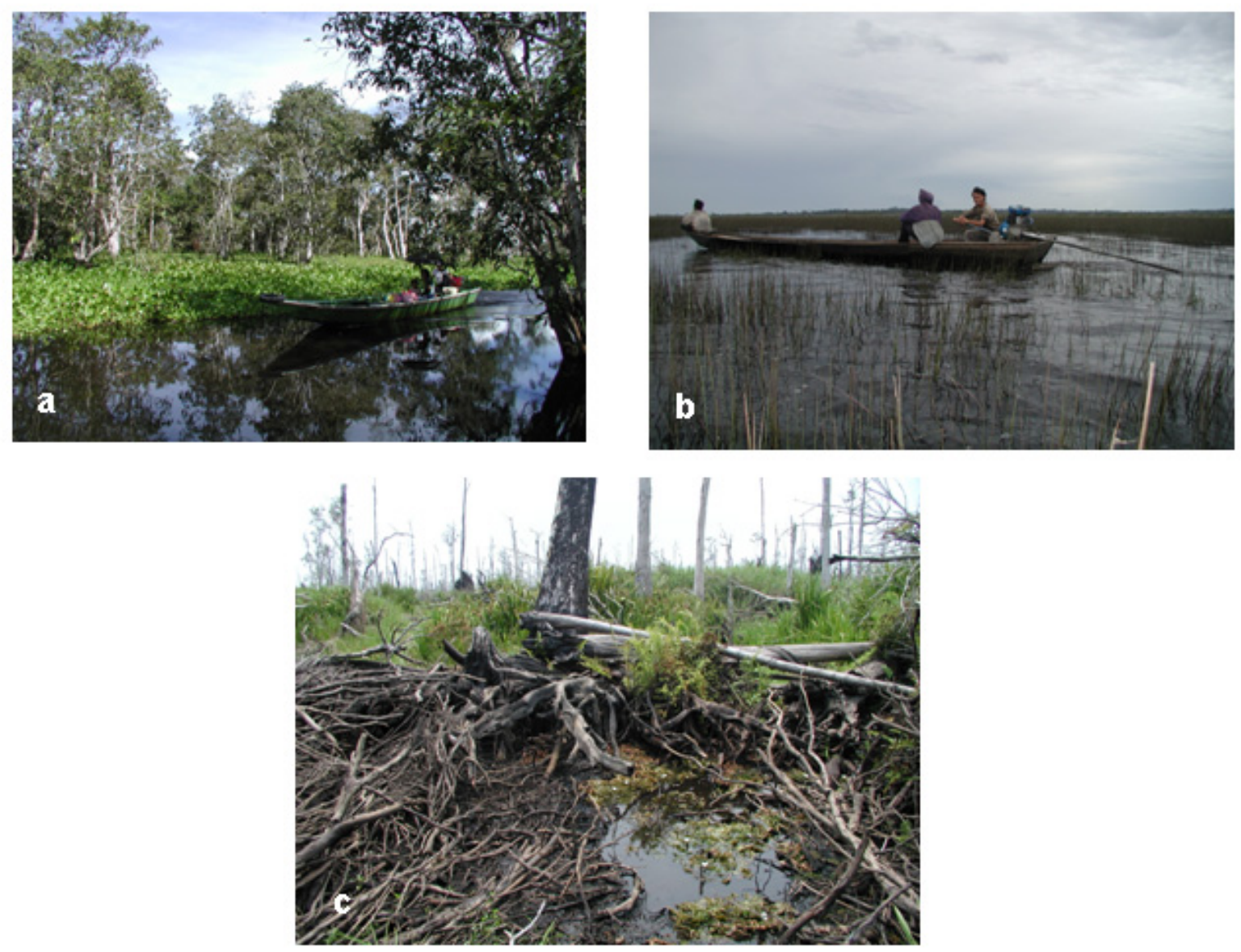

other forest products. Major rivers such as the Mahakam, Kedang Rantau, Kedang Kepala, and Belayan provided easy transport routes for ships, boats, and floating timber. The alluvial strips with flood clay soils allow agriculture and provide some timber, rattan, and other forest products (Richter 2000). In the peatlands, there was only limited harvesting of some wood species, such as Shorea balangeran for house construction and others for fuel wood. Harvesting was limited to about a $0.5 \mathrm{~km}$ distance from lakes and streams navigable by small boats in the flood season, and from where logs could be floated out. Some resin was collected before 1965 and tree bark in 1997-1998. Generally, the communities have a low direct value for the trees and other forest products available in the peatlands.

Fish is the economic and food mainstay for the dominant ethnic groups that live in the swamps, the Kutai and the Banjar. They have no traditional history of forest conservation and use, as do the communities of Dayak origin in Kalimantan (Colfer et al. 2000, 
Gönner 2002). The Middle Mahakam region serves as an important source of fish for the nation at large (MacKinnon et al. 1996). Financial returns from fishing are reputedly high, and harvests are substantial in and around the major peatlands (interviews, Christensen et al. 1986). Rising trends in fish harvests have been reported from the 1970s to 1997 (Christensen et al. 1986;

Wetlands International). Thus, communities do not view the burning, depletion, and transformation of peat swamp forests with alarm.

\section{- Technology and infrastructure development}

Household fish catches appear to have increased with the commercial introduction of nylon gillnets in 1982 (interviews, Christensen et al. 1986). Motorized boats and roads linked to logging, plantation, and transmigration projects have helped to increase links to markets. A perishable product such as fish is now delivered from the Middle Mahakam area to distant major markets like Banjarmasin within the same day, and commands high prices.

These developments have brought more people into the area and increased the importance of fishing, leading in turn to more use of fire. More directly, an extensive canal network built by villagers in the vicinity of Sungai Belayan has facilitated entry into and use of those peatlands.

- Communities perceive little negative impact

Local communities living in the swamps have neutral, if not positive, views of fire impacts and landscape transformation on fishing and livelihoods. They also perceive little negative impact on health and environmental functions, such as water quality and flooding. They suggest the prolonged droughts caused more problems by drying up waterways, making it harder to reach fishing areas and take the catch to the market. The long-term effects of the fires and landscape transformation on hydrology and fisheries need more detailed investigation. Some communities expressed concern about the loss of diversity of resources and hence potential alternative livelihoods in case the mainstay_fishing_collapsed.

Villages situated on the peatland periphery and, to an extent, dependent on rattan and other riverine and dryland forest products have suffered some negative impacts from the recent large-scale fires. The importance of fishing to the livelihood of many of these villages has increased over time.

\section{Driving Forces Behind the Extensive 1997- 1998 Drought-related Fires}

- Extremely dry conditions in both the vegetation and the peat soil, along with strong prevailing winds (Hoffmann et al. 1999) helped fires ignite and spread easily. Drying of the peat also enabled people to access the interior swamps on foot more easily.

- Low river levels and transport difficulties constrained regular livelihood options such as fishing. Alternative sustainable options were not apparent.

- New, high-value markets emerged for turtle meat, and for tree bark as an ingredient in commercial mosquito coils, encouraging widespread extraction of these resources using fire.

- The local government permitted quota-free collection of turtles to ease the economic crisis brought on by the drought, unaware of the potential ecological cost caused by large numbers of people accessing the interior swamps and using the important tool-firein their activities. 


\section{Likely Future Scenarios}

Fire will continue to be a major feature on the Middle Mahakam peatlands, where it is an important management tool. Recurrent fires will continue along waterways, adjacent sedge-grass floodplains, and scrub and secondary forests (covering up to $31 \%$ of the study site) to access fish and enhance fish habitat. These areas have largely herbaceous cover or even bare peat with some patches of Shorea balangeran trees and saplings (Chokkalingam et al. unpublished manuscript). Seed sources do exist in the vicinity. If left alone for longer periods of time, these areas could regenerate into secondary and then perhaps more mixed swamp forest, but this is unlikely to happen given the nature of land use involving repeated burning.

Useable areas will continue to expand inland, with adjacent disturbed forests being exposed to repeated fire. These forests will gradually be transformed into peat floodplains and lakes as tree cover disappears, regeneration is inhibited, and the peat collapses or is burned down to a low drought water table. This has apparently been a common historic practice throughout the area, resulting in the existing floodplains and shallow lakes (local respondents, Endert 1927, Hope et al. submitted manuscript). But the large-scale landscape alteration caused by the 1997-1998 fires and high population pressures on the resources will probably exacerbate the effects.

The bulk of the slightly to moderately burned interior peat forests, constituting up to $16 \%$ of the study site, show good potential for rapid regrowth (Chokkalingam et al. unpublished manuscript). This is similar to the rapid regrowth experienced in peat forests until 1997 following the fires of 1982-1983. Much of the interior forests that were more severely burned in 1997-1998 (up to 41\% of the study site that was converted to scrubby vegetation and sedgegrasslands) can also recover well if left alone. Local people rarely visit these interior areas in typical years.

However, these newly burned interior forest areas are in a highly flammable condition now. They carry substantial fuel loads of standing and fallen dead trees, and have dense understory and liana growth, and their open canopies promote rapid drying (Chokkalingam et al. unpublished manuscript). Another quick fire caused by a long drought in these areas will likely be more intensive, burn into the peat, destroy mixed swamp forest seed sources, and cause more severe, long-lasting damage. It would likely also have more serious regional and global impacts through smoke, haze, and carbon emissions. Given the dry and flammable conditions, fires could easily spread into these areas from burning on the boundaries. Also, in hard times, villagers may seek alternative resources within these regenerating areas. Furthermore, external policy and market support for such activities could again exacerbate the situation. A similar pattern of fire use and landscape change during long drought periods is reported for southern Sumatra (Chokkalingam et al. 2005).

\section{MANAGEMENT AND POLICY IMPLICATIONS}

\section{Local Needs vs. National and Global Concerns}

The Middle Mahakam case is highly representative of the emerging patterns of peatland use across Indonesia by local communities using fire to facilitate their agricultural, fishing, and other resource extraction activities. Expansion of such community use often follows large-scale logging, draining, and development activities; technological and market changes; or in response to constraints and opportunities posed by long drought periods. Extensive burning in the Middle Mahakam is a major contributor to the peat forest habitat loss, and smoke and greenhouse-gas pollution generated by peatland burning across Indonesia in recent decades.

What is the scope for resolving the trade-offs between the perceived local benefits of using fire and regional-to-global environmental concerns about widespread peatland burning, as embodied in the ASEAN haze pollution agreement, the ASEAN Peatland Management Initiative, the Ramsar convention, the International Convention on Biological Diversity, and the United Nations Framework Convention on Climate Change? Banning fires and policing the ban to conserve the peatlands and reduce pollution is not a viable option, because of the inaccessible and difficult terrain, the large numbers of people using fire, and the importance of fire for resource extraction in the peatlands. It has not been possible even to restrict use of the one, long-established 62 500-ha nature reserve on the site. Nor is it feasible or fair to move people (particularly long-term residents) out of these peatlands, which offer rich and productive 
fishing opportunities.

Some case studies indicated that the development of local community-based measures and resolution of land-tenure problems could be promising options for managing the fire and smoke problem (Hoare 2004, Tomich et al. 2004). However, in the swamps, specific provision of tenure rights alone is not likely to help reduce fire incidence, given little perceived negative impacts of fire use. Similar patterns exist in southern Sumatra where swamps-whether village, state, or privately owned-are all subject to the same type of land and fire use by the resident communities and migrants (Chokkalingam et al. 2005). Likewise, solely fostering local institutions, rules, and capacity to regulate use of fire in these swamps is also not likely to be effective because the communities benefit from the uncontrolled use of fire and have little incentive to regulate it.

\section{Possible Approach for Balancing Livelihoods and Environmental Concerns}

It is probably not possible or even necessary to prevent annual burning for fishing in the peatlands adjacent to the waterways. However, the gradual expansion of annual fires and forest degradation into the adjacent interior areas through escaped fires or deliberate burning to improve fishing should be stopped. Much of the interior areas of the Middle Mahakam peatlands could be rehabilitated to forest, perhaps as much as half of it, if burning during long drought periods could be prevented. This means preventing thousands of people from entering deep inside the forests in search of tree bark, turtles, or other such resources during severe droughts and other crises.

\section{RECOMMENDATIONS}

1. There is a need to develop and put in place an El Niño response program for the Middle Mahakam and other peatlands of Indonesia aimed at reducing fire use by communities and providing alternative sustainable livelihood options at these critical times. It is also important to raise awareness among government decision makers about the potential ecological costs of expanded swamp access in drought periods, which will inevitably be accompanied by fire use. It may be best to provide the alternative livelihood options outside of the peatlands given their extreme vulnerability in drought periods. Possible external livelihood options include infrastructural and small-scale industrial development in urban centers in the drylands. In the long-term, urban industrial development and job training could potentially help draw people away from the peatlands.

2. One conceivable option for protecting the interior peat forest areas while meeting local livelihood needs may lie in using transfer payments from external stakeholders to local communities for carbon and biodiversity conservation. Organizations concerned with fires in the peatlands of Central Kalimantan have already begun to explore such options, and lessons could be learned from there (Verhagen et al. 2004;

Global Peatlands Initiative). Any such schemes devised for the Middle Mahakam area will have to take into account the rich fishing opportunities that apparently benefit from fire use and the open-access resource regimes. Burgess et al. (2000) found that monetary incentives and conservation experts' perspectives were not enough to alter farmers' wetland practices in England. Farmers' behavior was a way of life based on their local knowledge and the local context, and these would need to be taken into account in the design of management schemes. This would probably be true for the Middle Mahakam area as well.

3. Overall, options that make sense to and directly benefit local communities are more likely to be accepted and adopted. In this context, it would be important to investigate whether recurrent widespread burning and landscape transformation have long-term negative impacts on the most valued resource, fish, or even on health and water quality. Such impacts are plausible, but not well established. Salmani (1987, cited by

Wetlands International) reports that three fish species once common in the Mahakam lakes are extremely rare now. In the wetlands of southern Sumatra, fisheries have declined over the last two decades, and the decline is variously attributed to recurrent widespread 
fires and landscape transformation, industrial pollution, and wetland reclamation (Chokkalingam et al. 2005). In comparison, the Middle Mahakam peatlands have experienced less intensive disturbance so far. Such information could be used to drive local interest in reducing uncontrolled fire use and conserving the interior peat forests, in assessing options and negotiating compromises and compensation.

4. In any strategy, it will be necessary to consider the technical and socioeconomic feasibility of practicing controlled burning in the accessible riverbanks and floodplains, particularly in long drought years, so that fires are contained. Appropriate incentives will have to be devised, communities will have to be convinced of the benefits and convenience of changing their practices, and local institutions and regulations will be required to support and implement the measures.

5. For currently remote, sparsely visited, forested wetlands of Indonesia, it is critical to reconsider development policies and plans, taking into account the potential consequences of increased land-use pressures, particularly in long drought years. Large-scale developments (transmigration, plantations, agriculture, commercial logging, and infrastructure) that deforest or drain the peatlands also improve access into the interior areas and increase the population pressures. Just bringing large numbers of people into still remote peatlands can have major environmental impacts. Even the relatively small development of a network of local fishing channels in the Middle Mahakam area improved access to fish and other resources, but also led to recurrent fires and degradation of the peat forest in that area. Once the landscape is transformed, a cycle of repeated fire and further environmental change sets in. Besides, most commercial logging and large pulpwood plantation and transmigration agriculture projects on peatlands in Indonesia have so far proven unsustainable (Brookfield et al. 1995, Dwiyono and Rachman 1996, Anderson and Bowen 2000, Page et al. 2002, Suyanto et al. 2004, World Wildlife Fund 2004).
Responses to this article can be read online at:

http://www.ecologyandsociety.org/vollo/iss 1/art26/responses/

\section{Acknowledgments:}

The work presented in this paper was partly funded by the European Union, through the project "The underlying causes and impacts of fires in Indonesia"; and by the Australian Centre for International Agricultural Research (ACIAR) through the project "Impacts of fire and its use for sustainable land and forest management in Indonesia and northern Australia." The authors would like to thank Afriastini, Andi Erman, Geoffrey Hope, Syaiful Anwar, Zainal Arifin, and the local communities of the Middle Mahakam area for their invaluable assistance and participation. Thanks are also due to the German Agency for Technical Cooperation (GTZ) Integrated Forest Fire Management project and the GTZ Sustainable Forest Management Project in Samarinda for logistical support and valuable background information, without which this study would not have been possible. Special thanks to Christoph Feldkotter and Sonya Dewi for important advice on methodology; to Claire Miller for editing; and to David Kaimowitz, Georg Buchholz, and Steve Rhee for their valuable comments.

\section{LITERATURE CITED}

Anderson, I. P., and M. R. Bowen. 2000. Fire zones and the threat to the wetlands of Sumatra, Indonesia. Report. MoFEC-EU Forest Fire Prevention and Control Project, Palembang, Indonesia.

\section{Asian Development Bank (ADB)/National Development Planning Agency (BAPPENAS). 1999. Causes, extent, impact and costs of 1997/98 fires and drought. final report, annex 1 and 2. Planning for Fire Prevention and Drought Management Project, Asian Development Bank, TA 2999-INO Fortech, Pusat Pengembangan Agribisnis, Margules Pöyry, Jakarta, Indonesia.}

Bock, C. 1991. The headhunters of Borneo: a 
narrative of travel up the Mahakkam and down the Barito, also journeying in Sumatra. Second edition. Oxford University Press, Singapore. (First published in 1881 by Sampson, Low, Marston, Searle and Rivington, London, UK.)

Brookfield, H., L. Potter, and Y. Byron. 1995. In place of the forest: environmental and socioeconomical transformation in Borneo and the eastern Malay Peninsula. United Nations University Press, Tokyo, Japan.

Burgess, J., J. Clark, and C. M. Harrison. 2000. Knowledges in action: an actor network analysis of a wetland agri-environment scheme. Ecological Economics 35:119-132.

Chokkalingam, U., and Suyanto. 2004. Summary of workshop results. Pages 20-34 in Suyanto, U. Chokkalingam, and P. Wibowo, editors. Kebakaran di Lahan Rawa/Gambut di Sumatera: Masalah dan Solusi. CIFOR, Bogor, Indonesia.

Chokkalingam, U., Suyanto, R. P. Permana, I. Kurniawan, J. Mannes, A. Darmawan, N. Khususyiah, and R. H. Susanto. 2005. Community fire use, resource change and livelihood impacts: The downward spiral in the wetlands of southern Sumatra. Mitigation and Adaptation Strategies for Global Change, in press.

Christensen, M. S., A. Mulu, and A. Akbar. 1986. Investigations into the fishery of the Middle Mahakam Area. German-Indonesian Technical Cooperation for Area Development, Samarinda, East Kalimantan, Indonesia.

Cochrane, M., A. Alencar, M. D. Schulze, C. M. Souza Jr., D. C. Nepstad, P. Lefebvre, and E. A. Davidson. 1999. Positive feedbacks in the fire dynamics of closed canopy tropical forests. Science 284:1832-1835.

Colfer, C., A. Salim, R. L. Wadley, and R. G. Dudley. 2000. Understanding patterns of resource use and consumption: a prelude to co-management. Borneo Research Bulletin 31: 29-88.

Dennis, R., A. Erman, and E. Meijaard. 2000. Fire in the Danau Sentarum landscape. Borneo Research Bulletin 31:123-137.

Dwiyono, A., and S. Rachman. 1996. Management and conservation of the tropical peat forest of
Indonesia. Pages 103-117 in E. Maltby, C. P. Immirzi, and R. J. Safford, editors. Tropical lowland peatlands of southeast Asia, Proceedings of a workshop on integrated planning and management of tropical lowland peatlands, 3-8 July 1992, Cisarua, Indonesia. IUCN, Gland, Switzerland.

Endert, F. H. 1927. Floristisch verslag. Pages 200 312 in Midden Oost Borneo Expeditie, 1925. Indisch Comite voor Wetenschappelijke Onderzoekingen. G. Kolff and Co., Weltervreden, The Netherlands.

Giesen, W., and Sukotjo. 1991. Conservation and management of the Ogan-Komering and Lebaks, South Sumatra. PHPA/AWB Sumatra Wetland Project Report No. 8. Directorate General of Forest Protection and Nature Conservation, Department of Forestry and Asian Wetland Bureau, Bogor, Indonesia.

Gönner, C. 2000. Wetland birds of Lake Jempang and the Middle Mahakam Area. Kukila 11:13-36.

Gönner, C. 2002. A forest tribe of Borneoresource use among the Dayak Benuaq. In $\mathrm{K}$. Seeland and F. Schmithûsen, editors. Man and Forest Series 3. D.K. Printworld (P) Ltd., New Delhi, India.

Hoare, P. 2004. A process for community and government cooperation to reduce the forest fire and smoke problem in Thailand. Agriculture, Ecosystems and Environment 104:35-46.

Hoffmann A. A., L. Schindler, and J. G. Goldammer. 1999. Aspects of a fire information system for East Kalimantan, Indonesia. Pages 176185 in H. Suhartoyo and T. Toma, editors. Impacts on fire and human activities on forest ecosystems in the Tropics, Proceedings of the $3^{\text {rd }}$ International Symposium on Asian Tropical Forest Management, 20-23 September 1999, Samarinda, Indonesia. Pusrehut Special Publication No. 8. Tropical Forest Research Center, Mulawarman University and Japanese International Cooperation Agency, Samarinda, Indonesia.

Hope, G., U. Chokkalingam, and S. Anwar. Submitted. A preliminary investigation of the stratigraphy and fire history of the Kutai peatlands, Kalimantan, Indonesia. Quaternary Research.

Jakubauskas, M. E., K. P. Lulla, and P. W. Mausel. 1990. Assessment of vegetation change in 
a fire altered forest landscape. Photogrammetric Engineering and Remote Sensing 56:371-377.

Jepson, P., F. Momberg, and H. van Noord. 1998. Trade in reptiles from the Middle Mahakam Lake Area, East Kalimantan, Indonesia, with evidence of a causal link to the forest fires associated with the 1997/98 El Niño phenomena. Bio-Regional Management and Integrated Park Management Project Technical Memorandum 3. World Wildlife Fund Indonesia/ United States Agency for International Development.

Lennertz, R., and K. F. Panzer. 1983. Preliminary assessment of the drought and forest fire damage in Kalimantan Timur. East Kalimantan Transmigration Area Development Project PN 76.2010.7. DFS German Forestry Inventory Service Ltd. for German Agency for Technical Cooperation (GTZ), Eschborn, Germany.

MacKinnon, K., G. Hatta, H. Halim, and A. Mangalik. 1996. The ecology of Kalimantan. Volume III. Periplus Editions, Singapore.

Maltby, E., and C. P. Immirzi. 1993. Carbon dynamics in peatlands and other wetlands soils: regional and global perspective. Chemosphere 27:999-1023.

Neuzil, S. G. 1997. Onset and rate of peat and carbon accumulation in four domed ombrogenous peat deposits in Indonesia. Pages 55-72 in J. O. Rieley and S. E. Page, editors. Biodiversity and sustainability of tropical peatlands. Samara Publishing Limited, Cardigan, UK.

Page, S. E., F. Siegert, J. O. Rieley, H.-D. V. Boehm, A. Jaya, and S. Limin. 2002. The amount of carbon release from peat and forest fires in Indonesia during 1997. Nature 420:61-65.

Richter, F. 2000. Structure and dynamics of riverine forest vegetation. TöB Series No: FTWF-19e. GTZ, Eschborn, Germany.

Rieley, J. O., and A. A. Ahmad-Shah. 1996. The vegetation of tropical peat swamp forests. Pages 5574 in E. Maltby, C. P. Immirzi, and R. J. Safford, editors. Tropical lowland peatlands of southeast Asia. IUCN, Gland, Switzerland.

Rieley, J. O., S. E. Page, S. H. Limin, and S. Winarti. 1997. The peatland resource of Indonesia and the Kalimantan peat swamp forest research project. Pages 37-44 in J. O. Rieley and S. E. Page, editors. Biodiversity and sustainability of tropical peatlands. Samara Publishing Limited, Cardigan, UK.

Schindele, W., W. Thoma, and K. Panzer. 1989. The forest fire 1982/83 in East Kalimantan. Part I: The fire, the effects, the damage and technical solutions. FR Report No. 5. DFS Deutsche Forstinventur-Service GmbH, GTZ and BPPK, Eschborn, Germany.

Shepherd, P.A., J. O. Rieley, and S. E. Page. 1997. The relationship between forest vegetation and peat characteristics in the upper catchment of Sungai Sebangau, Central Kalimantan. Pages 191-210 in J. O. Rieley and S. E. Page, editors. Biodiversity and sustainability of tropical peatlands. Samara Publishing Limited, Cardigan, UK.

Siegert, F., G. Ruecker, A. Hinrichs, and A. A. Hoffmann. 2001. Increased damage from fires in logged forests during droughts caused by El Niño. Nature 414:437-440.

Soetjipto, Suryanto, and A. Maas. 1996. Peatlands in Indonesia: their extent and utilization. Pages 155162 in E. Maltby, C. P. Immirzi, and R. J. Safford, editors. Tropical lowland peatlands of southeast Asia. IUCN, Gland, Switzerland.

Suyanto, U. Chokkalingam, and P. Wibowo. 2004. Kebakaran di Lahan Rawal Gambut di Sumatra: Masalah dan Solusi. Prosiding Semiloka (with English Summary), 10-11 December 2003, Palembang, South Sumatra. Center for International Forestry Research (CIFOR), Bogor, Indonesia.

Tacconi, L. 2003. Fires in Indonesia: causes, costs and policy implications. CIFOR occasional paper No. 38. CIFOR, Bogor, Indonesia.

Tomich, T. P., D. E. Thomas, and M. van Noordwijk. 2004. Environmental services and land use change in Southeast Asia: from recognition to regulation or reward? Agriculture, Ecosystems and Environment 104:229-244.

van Nieuwstadt, M. 2002. Trial by fire, postfire development of a tropical dipterocarp forest. Dissertation, Universiteit Utrecht, The Netherlands.

Verhagen, J., G. Meijerink, M. Schelhaas, H. 
Wösten, H. Diemont, and S. Limin. 2004. Strengthening the social dimension in research related to natural resources management. NorthSouth Policy Brief 2004-2. Programme International Cooperation, C/O North-South Centre, Wageningen, The Netherlands.

Weidemann, D. 2002. Development and extension of a Fire Danger Rating System for the province of East Kalimantan, Indonesia. Final Report. GTZMoFEC Integrated Forest Fire Management Project, Samarinda, Indonesia.

World Wildlife Fund (WWF). 2004. WWF concerns over the origins of fiber for the mills of the Asia Pulp and Paper Company in Sumatra, Indonesia. Report. (Online.) URL:

http://www.wwf.or.id/attachments/WWF Statement on APP 13Jul04 .pdf. 